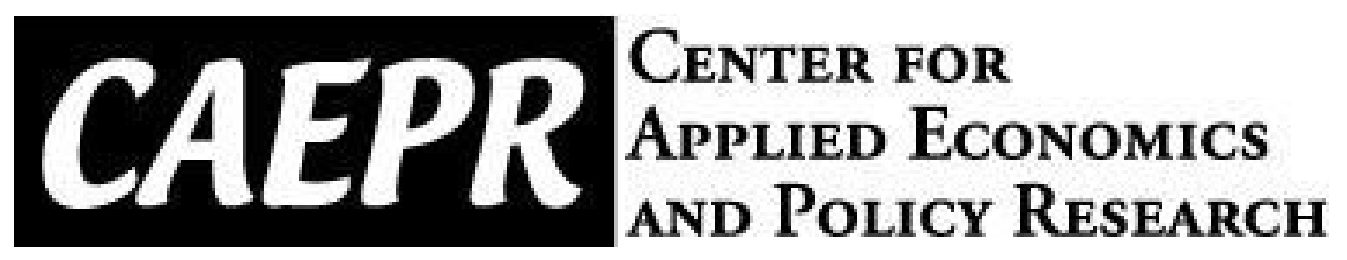

CAEPR Working Paper

\#2015-019

Foreign Exchange Interventions, Capital Controls and Monetary Policy: The Case of China

\author{
Hao Jin \\ Indiana University
}

October 15, 2015

This paper can be downloaded without charge from the Social Science Research Network electronic library at http://papers.ssrn.com/sol3/papers.cfm?abstract_id=2697223

The Center for Applied Economics and Policy Research resides in the Department of Economics at Indiana University Bloomington. CAEPR can be found on the Internet at:

http://www.indiana.edu/ caepr. CAEPR can be reached via email at caepr@indiana.edu or via phone at 812-855-4050.

(C2015 by Hao Jin. All rights reserved. Short sections of text, not to exceed two paragraphs, may be quoted without explicit permission provided that full credit, including (C) notice, is given to the source. 


\title{
Foreign Exchange Interventions, Capital Controls and Monetary Policy: The Case of China*
}

\author{
Hao Jin $^{\dagger}$
}

October 15, 2015

\begin{abstract}
China has maintained a closed capital account to the private sector and channeled capital flows through the public sector by foreign exchange interventions. This paper presents an open economy model that incorporates this capital account policy configuration in order to study whether foreign exchange interventions can improve welfare in the presence of capital controls, compared to an open capital account. Furthermore, I analyze how these interventions affect the conduct of monetary policy. I find that optimal interventions improve welfare by strategically managing the terms of trade. In the presence of domestic nominal rigidity, interventions increase welfare even if monetary policy is set optimally. I find monetary policy effectively eliminates domestic price distortions, while foreign exchange interventions efficiently correct terms-of-trade externalities.
\end{abstract}

Keywords: Foreign Exchange Interventions; Capital Controls; Monetary Policy; Chinese Economy; Welfare.

JEL Classification: D6; E52; F31; F38;

\footnotetext{
${ }^{*}$ This draft is preliminary.

${ }^{\dagger}$ Department of Economics, Indiana University, Wylie Hall Rm 105, 100 South Woodlawn, Bloomington, IN 47405-7104, USA. E-mail: jinhao@indiana.edu
} 


\section{INTRODUCTION}

China's integration into the global trade market has been rapid and pronounced since the early 1980s. Figure 1 shows that the trade volume ${ }^{1}$ accounts for no more than $15 \%$ of GDP when the integration started; in less than three decades it reaches over $60 \%$ of GDP. Despite the removal of trade barriers, capital account policy reform has shown little progress. Figure 2 plots the Chinn and Ito (2006) capital account openness index for China against the world average. Not only is China's capital account openness far below the world average, it remains unchanged throughout this period of trade integration.

The strict regulations on capital flows almost fall entirely on the private sector and capital flows are channeled through the public sector in China, which I call it a semiopen capital account regime. ${ }^{2}$ The government in this capital account policy regime acts as a financial intermediary that issues bonds to absorb domestic savings, and uses the proceeds to purchase foreign reserves, and vice versa. In practice, this operation is referred to as "sterilized foreign exchange interventions." Due to this policy arrangement and the large surplus from trade, China's holdings of foreign reserves have grown rapidly since the trade integration, as shown in figure 3. As a consequence, management of China's capital account policy regime attracts considerable attention from the policy makers.

This paper studies whether a semi-open capital account can be welfare improving compared to an open capital account. The paper also examines the effects of the semiopen capital account on the conduct of monetary policy. I address this question in a standard open economy model with country-specific products. The country-specific goods assumption can be interpreted as a reduced-form way to capture China's comparative advantage in producing labor-intensive goods. In this model, a terms of trade externality arises naturally. When private agents make production decisions, they do not consider the effect of their actions on the relative prices of the home output. For example, if a country improves its productivity, private agents would borrow from abroad to invest and produce more. However, the increased supply of goods in the international market drives down their relative prices. This terms of trade deterioration may be so large that the total income the country receives from selling its products in the international market is even lower than before productivity improvement. A social planner would internalize this terms-of-trade externality and produce less com-

\footnotetext{
${ }^{1}$ The trade volume is measured as total imports plus exports.

${ }^{2}$ Bacchetta, Benhima and Kalantzis (2013) names this policy configuration a semi-open economy.
} 


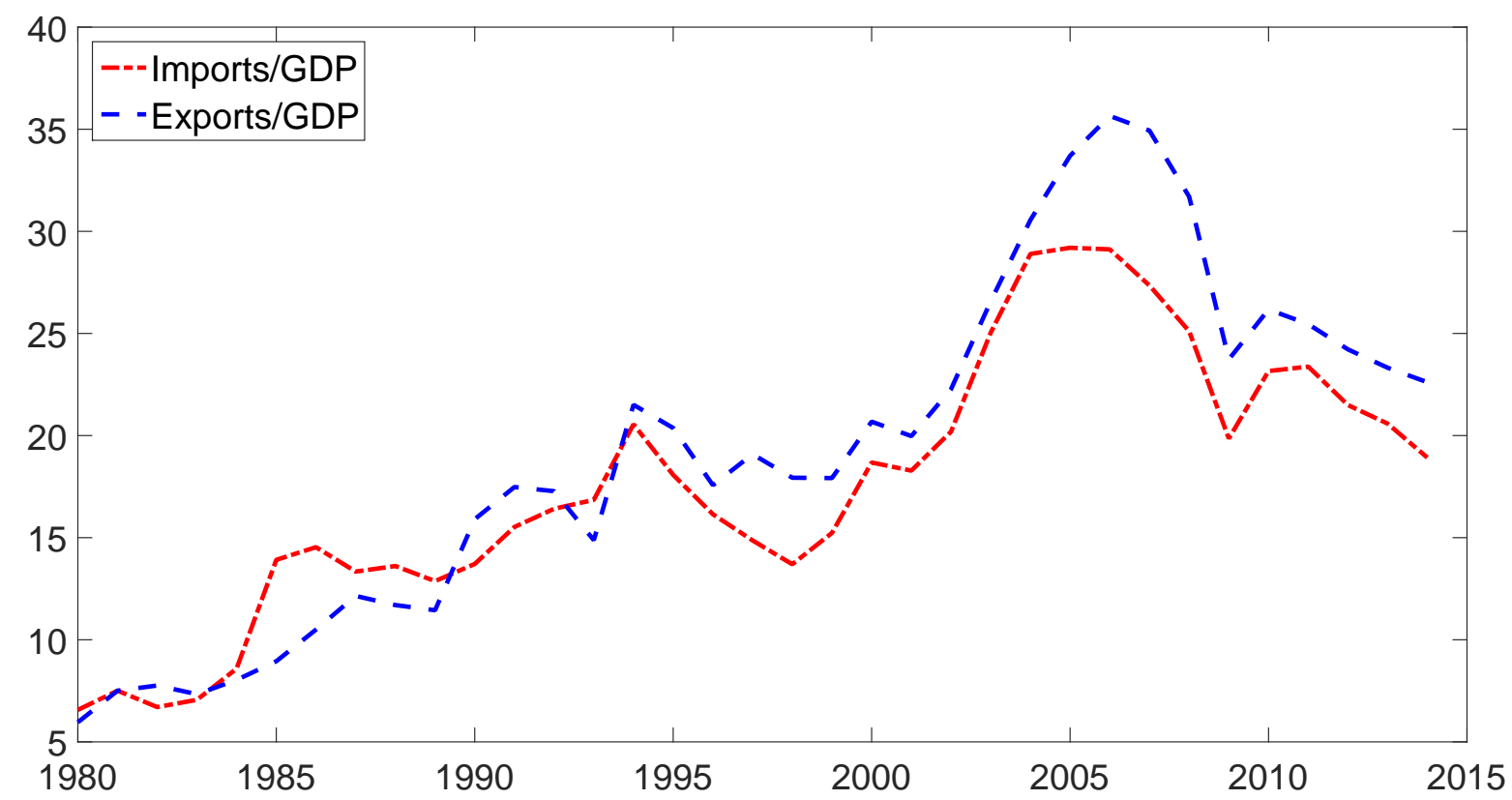

Figure 1: China's Imports and Exports over GDP(\%)

Data Source: China National Bureau of Statistics(NBS). The dash-dot and dashed lines show China's imports and exports over GDP ratio in percentage respectively.

pared to the competitive allocations. One way for the government to manage the terms of trade is through the use of foreign exchange interventions in the presence of capital controls on private capital flows, i.e. adopting a semi-open capital account policy regime. By shutting down private access to the international bond market and allowing the public sector to accumulate international bonds in the foreign exchange market, the government is able to achieve a socially optimal level of capital flows.

Although foreign exchange interventions are certainly not the only options available to the government to influence capital flows, they are valuable. Two main arguments characterize the benefits of incorporating foreign exchange interventions into the policy maker's toolbox. First, although state-contingent capital controls have been suggested to restrict capital flows to achieve various goals, such as terms of trade manipulation and macro-prudential considerations, ${ }^{3}$ foreign exchange interventions offer more flexibility. The work by Eichengreen and Rose (2014) documents that capital controls rarely adjust with short-term macroeconomic variables because of the negative signal it may send out to the market, and the legislation time lag to institute them. This is consistent with the evidence in figure 2 showing that China has not reformed

\footnotetext{
${ }^{3}$ See for example Farhi and Werning (2014) for the use of capital controls to manage terms of trade and Bianchi (2011), Jeanne and Korinek (2010) and Korinek (2010) for the macro-prudential objective.
} 


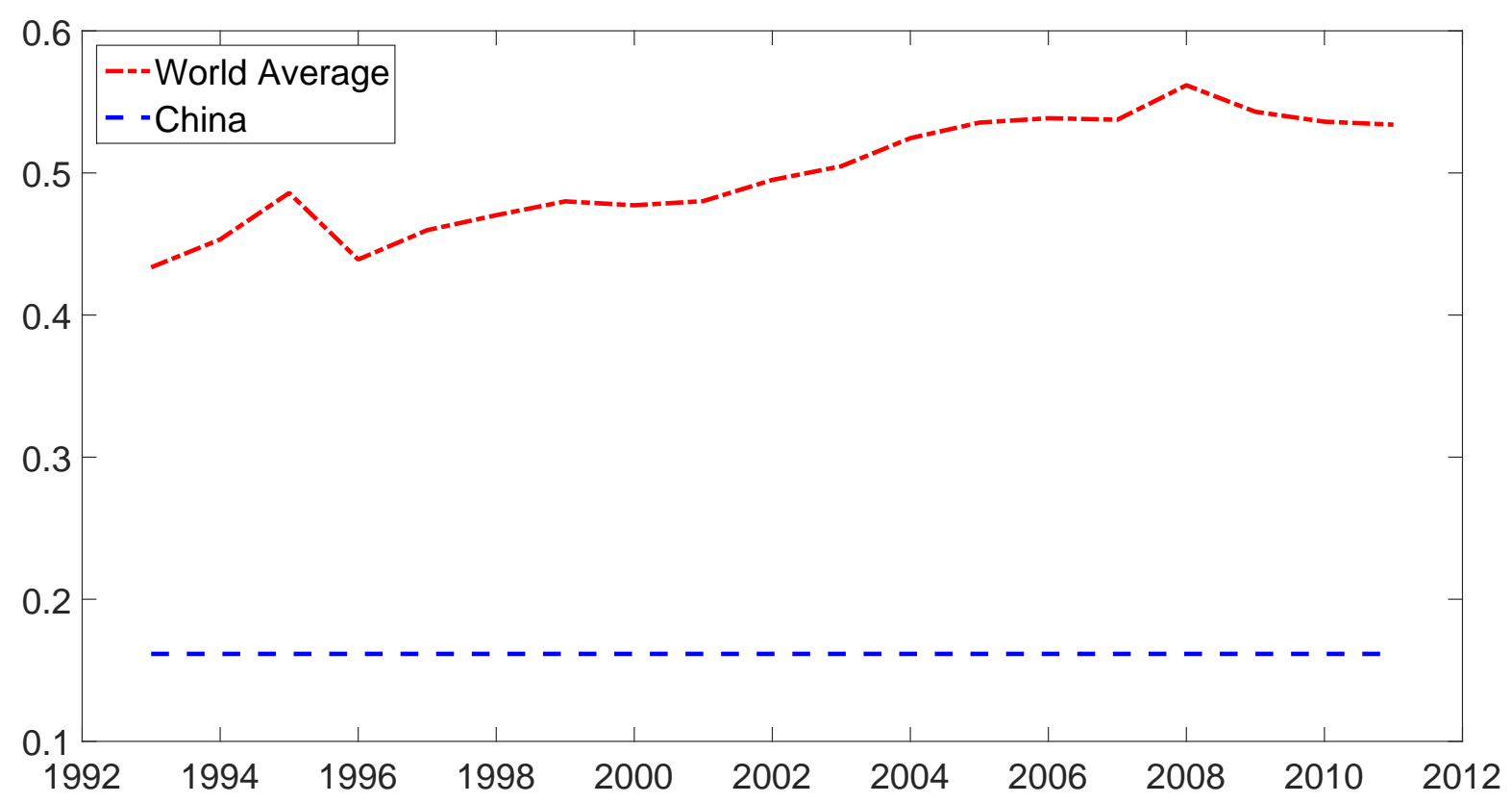

Figure 2: Chinn-Ito Capital Account Openness Index

Data Source: Chinn and Ito (2006). The dash-dot and dashed lines show China and world average capital account openness index respectively.

its capital account policy substantially over the past two decades. Due to the existence of political and practical obstacles in implementing a state-contingent capital control policy, the results in this paper suggest that foreign exchange interventions can be undertaken to complement a constant level of capital control and improve welfare.

Second, foreign exchange interventions in the presence of capital controls can be welfare enhancing even if monetary policy chooses the interest rate optimally. When nominal rigidities are present, in general it is not desirable for the monetary policy to anchor inflation at zero for an open economy with imperfectly substitutable products. ${ }^{4}$ In this setting policy makers face two targets, inflation distortions and the terms-oftrade externality, but only one tool, the interest rate. Policy must balance the benefit of a favorable terms of trade with the cost of greater price distortions. This paper demonstrates that including foreign exchange interventions as additional policy instruments creates a more efficient outcome by relaxing the policy constraints faced by policy makers, allowing them to strategically choose a path of terms of trade without destabilizing the price level. More interestingly, I find that monetary policy is a more power tool to cope with domestic price distortions, while foreign exchange interventions target

\footnotetext{
${ }^{4}$ Corsetti and Pesenti (2001), Benigno and Benigno (2003) and De Paoli (2009), among others, provide excellent theoretical investigations on this issue.
} 


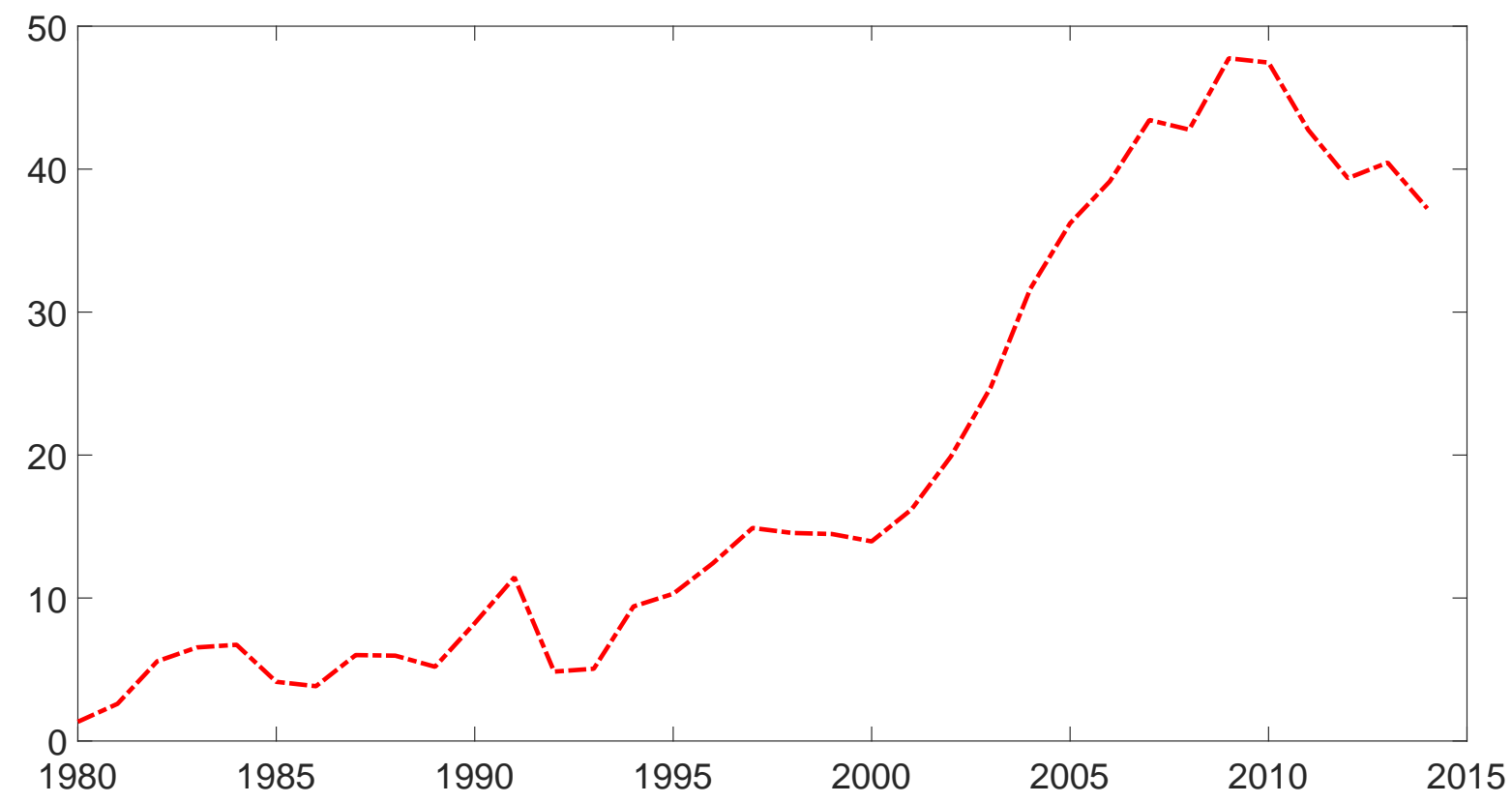

Figure 3: China's Foreign Reserve/GDP(\%)

Data Source: World Bank. Total reserves comprise special drawing rights, reserves of IMF members held by the IMF, and holdings of foreign exchange under the control of monetary authorities. Gold holdings are excluded.

terms-of-trade externalities more effectively. This implies that, although this not a case for restricting free capital movements under fixed exchange rate arrangement to retain independent monetary policy, as in Farhi and Werning (2012) and Schmitt-Grohé and Uribe (2012), monetary policy should concentrate on domestic nominal frictions and leave the external adjustments to open macroeconomic policy.

The macroeconomic implications from the optimal conduct of interventions in a semi-open capital account are the following: When domestic productivity improves, private agents want to borrow from abroad to invest and produce, but private capital flows are restricted. The public sector acts as a financial intermediary that borrows from the international bond market and lends to domestic agents in local currency bonds, but at a smaller amount than the private sector's desired level. This stabilizes domestic output, international goods trade, and relative price movements. In response to a rise of the foreign interest rate, a benevolent government saves less or borrows more from overseas to combat the drop of aggregate demand for home production. This mitigates the negative impact of the external shock, and stabilizes the domestic economy. Notice that the exchange rate regime is assumed to be flexible, however the optimal policy responses to shocks keeps real exchange rate relatively stable, though 
not fixed, compared to the equilibrium in an open capital account policy regime.

\section{LiterATURE REVIEW}

This paper is directly linked to the normative studies of foreign exchange interventions. Devereux and Yetman (2014) examine the effect of including foreign exchange intervention as an additional policy tool on global welfare. Although they reach the same conclusion that it gives policy makers more freedom in maximizing welfare, they focus on how the effectiveness of interventions is affected by exchange rate pass through, and integration of world goods and financial markets, I instead highlight how interventions interact with capital controls and monetary policy. This paper is closely related to Prasad (2014) in which the author studies optimal interventions under capital controls in a small open economy. We both find that interventions can be welfare improving in this case because of the existence of a terms-of-trade externality. However, my model features endogenous capital accumulation which is not only important to fit the model to Chinese data, but also influences the current account movements since investment goods flow across boarders as well as consumption goods. In some cases, my model shows opposite current account balance on impact in contrast to the models without capital accumulation. Chang, Liu and Spiegel (2015) discuss optimal monetary policy under China's unique external policy configuration, capital controls, exchange rate peg and sterilized interventions, as I do in this paper. However, in contrast to their approach to set up the interventions to follow a simple response rule, I analyze the optimal interventions and monetary policy jointly.

Another more recent growing strand of literature studies the optimal use of capital controls to regulate capital flows for the purpose of terms of trade management. Some examples include De Paoli and Lipinska (2013), Farhi and Werning (2014) and Heathcote and Perri (2014). While this paper addresses the same source of inefficiency, I differ from them by proposing the, more flexible, joint use of a fixed level of capital controls and state-contingent interventions to restrict capital flows and improve welfare. Capital control has been also suggested to be used to prevent endogenous financial crisis as in Bianchi (2011), Jeanne and Korinek (2010) and Korinek (2010). I abstract from the macro-prudential consideration of foreign exchange interventions.

Finally, a large number of papers have devoted their attention to the use of monetary policy to deal with price distortions and terms-of-trade externalities. They find the domestic price level fluctuates as an optimal outcome because monetary policy has

an incentive to deviate from flexible price equilibrium to obtain a more favorable terms 
of trade. I demonstrate in this paper that adding foreign exchange interventions to the policy makers' toolbox is beneficial, formally confirming the two targets, two instruments result in Chamon, Ostry and Ghosh (2012). I find monetary policy effectively eliminates price distortions, while foreign exchange interventions efficiently correct the terms-of-trade externality.

\section{MODEL}

In this section I incorporate China's external policies into an otherwise standard open economy DSGE model. This open economy takes international interest rate as given, but produces country-specific intermediate goods that are imperfect substitutes to foreign goods and are required in final output. The country-specific goods assumption can be interpreted as a reduced-form way to capture China's comparative advantage in producing labor-intensive goods. The asset market is incomplete and only one-period risk-free bonds are traded.

3.1 HouseHOlDS This open economy is populated by an infinitely lived representative household that derives utility from consumption, $c_{t}$, and disutility from hours worked, $l_{t}$. Specifically, the household chooses a sequence of consumption, hours worked, capital investments and savings in domestic government bonds and international bonds to maximizes lifetime utility given by:

$$
\mathbb{E}_{0} \sum_{t=0}^{\infty} \beta^{t}\left[\frac{c_{t}^{1-\frac{1}{\sigma}}}{1-\frac{1}{\sigma}}-\chi \frac{l_{t}^{1+\eta}}{1+\eta}\right]
$$

where $0<\beta<1$ is the discount factor, $\sigma>0$ is the household's risk aversion and $\eta>0$ is the inverse of the Frisch labor elasticity. $\chi$ is an additional parameter to ensure that in deterministic steady state, labor hours constitute one third of time endowment.

The household receives interest income from domestic and international oneperiod risk-free nominal bonds, capital investment return, labor income and lump-sum transfers from the government. The household consumes, invests in domestic capital market and saves in domestic and international bonds, $B_{t}^{G}$ and $B_{t}^{F}$ respectively. Trading in the domestic government bond market involves no additional cost, while adjusting positions in the international bond market incurs a quadratic transaction cost. 
The household's flow budget constraint is given by

$$
\begin{aligned}
P_{t} c_{t}+P_{t} i_{t}+B_{t}^{G}-S_{t} B_{t}^{F}+P_{t} \Gamma_{f}\left(\frac{S_{t} B_{t}^{F}}{P_{t}}\right)= & W_{t} l_{t}+R_{t-1}^{k} k_{t-1} \\
& +R_{t-1} B_{t-1}^{G}-R_{t-1}^{*} S_{t} B_{t-1}^{F}+P_{t} z_{t},
\end{aligned}
$$

where $W_{t}$ is the nominal wage rate for labor input $l_{t}$ and $R_{t-1}^{k}$ is the nominal rate of return for capital supplied $k_{t-1}$. Capital stock accumulation follows a linear law of motion,

$$
k_{t}=(1-\delta) k_{t-1}+i_{t}
$$

where $\delta$ is the capital depreciation rate.

Domestic government bonds pay gross nominal interests $R_{t}$ every period, whereas the foreign bonds pay $R_{t}^{*}$ gross nominal interests in foreign currency. $S_{t}$ is the nominal exchange rate expressed as domestic currency in terms of dollars. $B_{t}^{G}>0$ means households save in domestic market, and $B_{t}^{F}>0$ means households borrow from overseas.

Adjusting international asset positions requires a quadratic portfolio adjustment cost in terms of real domestic consumption goods, $\Gamma_{f}\left(\frac{S_{t} B_{t}^{F}}{P_{t}}\right)$, where $\Gamma_{f}\left(\frac{S_{t} B_{t}^{F}}{P_{t}}\right) \equiv$ $\frac{\gamma_{f}}{2}\left(\frac{S_{t} B_{t}^{F}}{P_{t}}-b^{F}\right)^{2}$ and $b^{F} \equiv \frac{B^{F} S}{P}$ denotes the steady state value of real foreign bond holdings $\frac{S_{t} B_{t}^{F}}{P_{t}}$. This follows Schmitt-Grohé and Uribe (2003) to ensure a stationary steady state exists in the model. I choose a very small $\gamma_{f}$ in the model calibration to gurantee stationarity. ${ }^{5}$

Divide the household budget constraint by the home aggregate price level $P_{t}$ and the optimal choices of domestic and international bond holdings imply that

$$
\lambda_{t}=\beta R_{t} E_{t} \frac{\lambda_{t+1}}{\pi_{t+1}}
$$

and

$$
\lambda_{t} e_{t}\left[1-\gamma_{f}\left(b_{t}^{F} e_{t}-b^{F} e\right)\right]=\beta R_{t}^{*} \mathbb{E}_{t} \frac{\lambda_{t+1}}{\pi_{t+1}^{*}} e_{t+1}
$$

where $\lambda_{t}$ is the Lagrangian multiplier for the household's budget constraint and denote the domestic and foreign inflation rates by $\pi_{t+1} \equiv \frac{P_{t+1}}{P_{t}}$ and $\pi_{t+1}^{*} \equiv \frac{P_{t+1}^{*}}{P_{t}^{*}}$ respectively.

\footnotetext{
${ }^{5}$ I perform robustness checks to make sure the model dynamics is not driven by this assumption.
} 
$e_{t} \equiv S_{t} \frac{P_{t}^{*}}{P_{t}}$ is the real exchange rate, expressed as the amount of home final goods per unit of foreign final goods.

The first optimality condition (3.4) gives us the standard consumption Euler equation, which states that the marginal rate of substitution between today and tomorrow's consumption must equal to the discounted real return. The second first order condition (3.5) shows that for domestic investors to be willing to hold foreign assets, the intertemporal marginal rate of substitution must equal to the foreign real return, adjusted for expected changes of exchange rate $\mathbb{E}_{t} \frac{e_{t+1}}{e_{t}}$, transaction costs, and discounting.

\subsection{FIRMS}

3.2.1 FinAl GoOdS FIRMS A representative final-good firm combines the domestically produced and imported intermediate goods to produce final non-tradable goods that are used for both consumption and investment. The final good is assumed to be produced by a CES aggregation technology,

$$
y_{t}=\left[(1-v)^{\frac{1}{\mu}}\left(y_{t}^{H}\right)^{\frac{\mu-1}{\mu}}+v^{\frac{1}{\mu}}\left(y_{t}^{F}\right)^{\frac{\mu-1}{\mu}}\right]^{\frac{\mu}{\mu-1}},
$$

where $\mu>0$ is the elasticity of substitution between home and foreign intermediate goods, and $0 \leq v \leq 1$ determines the share of local and imported goods in the composition of domestic final goods.

The final good producer chooses the following domestically produced and imported intermediate good bundles to maximize profits,

$$
\begin{gathered}
y_{t}^{H}=(1-v)\left(p_{t}^{H}\right)^{-\mu} y_{t}, \\
y_{t}^{F}=v\left(p_{t}^{F}\right)^{-\mu} y_{t},
\end{gathered}
$$

where $p_{t}^{H} \equiv \frac{P_{t}^{H}}{P_{t}}$ and $p_{t}^{F} \equiv \frac{P_{t}^{F}}{P_{t}}$ are the relative prices of home and imported intermediate goods to the final goods.

The aggregate price index $P_{t}$ is given by,

$$
P_{t}=\left[(1-v)\left(P_{t}^{H}\right)^{1-\mu}+v\left(P_{t}^{F}\right)^{1-\mu}\right]^{\frac{1}{1-\mu}}
$$

3.2.2 INTERMEDIATE GOODS FIRMS The home country consists of a continuum of monopolistically competitive firms producing a differentiated intermediate good using labor and capital. Production of good $j$ is given by a Cobb-Douglas production 
function,

$$
Q_{t}^{H}(j)=\exp \left(a_{t}\right) k_{t}^{\alpha}(j) l_{t}^{1-\alpha}(j)
$$

where $a_{t}$ is a technology shock that follows an AR(1) process,

$$
a_{t}=\phi_{a} a_{t-1}+\varepsilon_{t}^{a}
$$

where $\varepsilon_{t}^{a}$ is an i.i.d disturbance with standard deviation $\sigma_{a}$.

The markets for labor and capital are assumed to be perfectly competitive such that the capital-labor ratio is given by,

$$
\frac{k_{t}}{l_{t}}=\frac{w_{t}}{r_{t}^{k}} \frac{\alpha}{1-\alpha}
$$

Firms that minimize production costs have identical marginal costs given by $M C_{t}=$ $(1-\alpha)^{\alpha-1} \alpha^{-\alpha}\left(R_{t}^{k}\right)^{\alpha} W_{t}^{1-\alpha} \exp \left(a_{t}\right)^{-1}$.

The aggregation technology for intermediate goods bundles is given by,

$$
Q_{t}^{H}=\left[\left(\int_{0}^{1} Q_{t}^{H}(j)^{\frac{1}{1+\epsilon}} d j\right)\right]^{1+\epsilon}
$$

where $\epsilon$ determines the elasticity of substitution between the differentiated home and foreign intermediate goods.

Cost minimization by the final good producer implies the following individual home intermediate goods demand functions,

$$
y_{t}^{H}(j)=\left(p_{t}^{H}(j)\right)^{-\frac{1+\epsilon}{\epsilon}} y_{t}^{H}
$$

where $p_{t}^{H}(j) \equiv \frac{P_{t}^{H}(j)}{P_{t}^{H}}$ denotes the relative price of firm j's intermediate goods to home goods. $P_{t}^{H}(j)$ is the price charged by firm $\mathrm{j}$ in the domestic market and $P_{t}^{H}$ is the domestic aggregate price index. $y_{t}^{H}$ is the aggregate domestic demand.

The price setting is assumed to be sluggish following Calvo. Each period a fraction $\omega$ of firms cannot adjust their price. Firms that are allowed to re-optimize their price at time $t$ maximize expected discounted profits,

$$
\mathbb{E}_{t} \sum_{k=0}^{\infty}(\beta \omega)^{k} \frac{\lambda_{t+k}}{\lambda_{t}}\left[p_{t}^{H}(j) y_{t+k}^{H}(j)-M C_{t+k} y_{t+k}^{H}(j)\right]
$$


subject to individual firm's output demand (3.14).

3.3 FOREIGN ECONOMY I denote all the foreign variables with a superscript asterisk. The foreign demand for home produced intermediate goods is assumed to be,

$$
y_{t}^{H^{*}}=v^{*}\left(p_{t}^{H^{*}}\right)^{-\mu^{*}} y_{t}^{*}
$$

where $p_{t}^{H^{*}} \equiv \frac{P_{t}^{H^{*}}}{P_{t}^{*}}$ is the relative price of home intermediate export goods to foreign goods. $P_{t}^{H^{*}}$ is the foreign currency price of domestic produced intermediate goods and $P_{t}^{*}$ is the foreign price index. $y_{t}^{H^{*}}$ consists the domestic exports to the foreign economy. This foreign demand curve is analogous to the home demand curve and can be derived from a symmetric foreign firm's problem. To keep the analysis simple and highlight the key mechanism, I do not model the foreign country explicitly, and treat the foreign output, price level and interest rate as exogenous.

I assume the exporting industry to be perfectly competitive, which implies home exporters are price takers, and the law of one price holds for export prices $P_{t}^{H^{*}} S_{t}=P_{t}^{H}$. Similarly, home imports are competitively priced as well. A foreign representative firm exports to home as long as the price is equal to the foreign price adjusted for exchange rate. In other words, we should have $P_{t}^{F}=S_{t} P_{t}^{F^{*}}$ in equilibrium, where $P_{t}^{F^{*}}$ is the price of foreign goods in foreign market.

3.4 Terms of Trade and Real Exchange Rate The terms of trade is defined as the export prices over the import prices, $T o T_{t} \equiv \frac{p_{t}^{H}}{p_{t}^{k}}$. Rewrite the terms of trade as,

$$
\mathrm{ToT}_{t}=\frac{S_{t} P_{t}^{*}}{P_{t}^{H}}
$$

and use the definition of real exchange rate,

$$
e_{t}=\frac{S_{t} P_{t}^{*}}{P_{t}}
$$

to obtain a relationship that links the real exchange rate to terms of trade,

$$
e_{t}=\left[(1-v) T_{o} T_{t}^{\mu-1}+v\right]^{\frac{1}{\mu-1}} .
$$

Since $\mu \leq 1$, (3.19) demonstrates that the real exchange rate and terms of trade always move proportionally in opposite directions. If the law of one price does not hold, 
for example because of the assumption of Local Currency Pricing (LCP) ${ }^{6}$, where each intermediate good's price is set independently (and potentially sticky) in various markets, then the tight connection between real exchange rate and terms of trade no longer holds.

3.5 Government Budget CONSTRAint The government issues one period nominal bonds $B_{t}^{G}$ in the domestic market to finance its interest payments, purchases of foreign reserves $B_{t}^{F R}$, fixed expenditure $G$ and lump-sum transfers $z_{t}$ to the households. Lump-sum transfers adjust to ensure that the government is solvent. Foreign exchange intervention is assumed to be fully sterilized such that the government supplies more (less) domestic currency to offset foreign currency inflows (outflows) associated with international trade, and simultaneously sells (buys) domestic bonds to absorb the increased (decreased) money supply. As a consequence, the size of the government's balance sheet is unchanged, only the composition changes.

The government's flow budget constraint is given by

$$
B_{t}^{G}-B_{t}^{F R} S_{t}=R_{t-1} B_{t}^{G}-R_{t-1}^{*} B_{t-1}^{F R} S_{t}+P_{t} z_{t}+P_{t} G
$$

3.6 BALANCE Of PAyment The balance of payment of this open economy is written as,

$$
-B_{t}^{F} S_{t}-B_{t}^{F R} S_{t}=P_{t}^{H^{*}} S_{t} Y_{t}^{H *}-P_{t}^{F} Y_{t}^{F}-R_{t-1}^{*} S_{t} B_{t-1}^{F}-R_{t-1}^{*} B_{t-1}^{F R} S_{t}
$$

Imports and exports of goods are free of barriers. This represents the open trade policy China adopts in the early 2000s after joining the WTO. The capital account on the other hand is tightly regulated. I define the capital account regimes below in section 3.8.

3.7 Market Clearing CONDitions The final goods and the intermediate goods markets clear,

$$
\begin{gathered}
Y_{t}=C_{t}+I_{t}+G+\Gamma_{f}\left(\frac{S_{t} B_{t}^{F}}{P_{t}}\right), \\
Q_{t}^{H}=Y_{t}^{H}+Y_{t}^{H *} .
\end{gathered}
$$

In addition, domestic and international bond markets clear.

\footnotetext{
${ }^{6}$ See Betts and Devereux (1996) for more details about the LCP assumption.
} 


\subsection{Definition of CAPITAl Account Regimes I classify capital account policy} into the following three broad regimes, which depend on the policy instruments available to the policy makers.

Definition 1. The capital account regimes are defined as:

i) Open capital account (Open $C A$ ) regime, where $B_{t}^{F} \in \mathbb{R}$ and $B_{t}^{F R}=0, \forall t$.

ii) Semi-open capital account (Semi-open $C A$ ) regime, where $B_{t}^{F}=0$ and $B_{t}^{F R} \in \mathbb{R}, \forall t$.

iii) Closed capital account (Closed $C A$ ) regime, where $B_{t}^{F}=0$ and $B_{t}^{F R}=0, \forall t$.

In the open capital account regime, a country's international bond holding is determined solely by the domestic private agents without any interventions. In contrast, a country's foreign bond position is completely controlled by the government in the semi-open capital account regime. In this case, the government acts as a financial intermediary between the domestic private sector and the international bond market, as suggested by Song, Storesletten and Zilibotti (2011). In the closed capital account regime, since the country is in financial autarky, neither private nor public sector has access to international bond market.

\subsection{Definition of Equilibrium under Open Capital Account Regime An} equilibrium under an open capital account as in definition 1 is competitive and consists a set of prices such that the households maximize their utility (3.1) subject to the sequence of budget constraints (3.2) for all $t \geq 0$, taking these prices as given. Firms maximize their profits subject to the production technology, (3.6), (3.10) and (3.13), taking these prices as given. Finally, all markets clear.

\subsection{Definition of Equilibrium under Semi-open Capital Account Regime} Next, we consider the optimal foreign exchange interventions under the semi-open capital account regime as a Ramsey problem. The Ramsey planner's problem consists of maximizing (3.1) subject to the sequence of country level budget constraints (3.21) under semi-open capital account regime and government budget constraints (3.20) for all $t \geq 0$, all the households' and firms' optimality conditions, ${ }^{7}$ except that households do not have access to the international bond market, which implies condition (3.5) no longer holds. Finally, all markets clear.

\subsection{A Comparison Between Two Capital Account Regimes To see why the} allocations may differ across the two regimes, let us consider a social planner's problem. The planner knows that a country's supply of goods to the international market

\footnotetext{
${ }^{7}$ See Appendix A for the first order conditions under competitive equilibrium.
} 
has an impact on the relative prices of their products, and internalizes this price effect when allocating production resources. Private agents instead take relative prices as given when making their production decisions.

Under competitive equilibrium, the firm's demand functions of labor and capital are given by the following equations,

$$
\begin{gathered}
w_{t}=(1-\alpha) \frac{p_{t}^{H} Q_{t}^{H}}{l_{t}} \\
r_{t}^{k}=\alpha \frac{p_{t}^{H} Q_{t}^{H}}{k_{t}}
\end{gathered}
$$

Under planner equilibrium, the relative prices $p_{t}^{H}$ are no longer taken as exogenous when optimizing. Therefore, the optimality conditions with respect to labor and capital become,

$$
\begin{gathered}
w_{t}=(1-\alpha) \frac{p_{t}^{H} Q_{t}^{H}}{l_{t}}+\underbrace{Q_{t}^{H} \frac{\partial p_{t}^{H}}{\partial l_{t}}}_{\text {price effect }}, \\
r_{t}^{k}=\alpha \frac{p_{t}^{H} Q_{t}^{H}}{k_{t}}+\underbrace{Q_{t}^{H} \frac{\partial p_{t}^{H}}{\partial k_{t}}}_{\text {price effect }},
\end{gathered}
$$

where $p_{t}^{H}=\left[(1-v)\left(\frac{y_{t}}{y_{t}^{H}}\right)\right]^{\frac{1}{\mu}}$ according to the demand for home intermediate goods (3.7).

The right hand sides of (3.24) and (3.26) represent the marginal product of hiring an additional labor hour and the left hand sides are the real wage rate. When each individual firm makes its own production decision, the firm takes the relative prices of its output as given. However, the planner knows that when the country's supply of goods increases, the relative prices of its output are affected. This price effect is captured in the last term of equation (3.26). If more production suppress the relative prices of domestic output, i.e. $\frac{\partial p_{t}^{H}}{\partial l_{t}}<0$, this in turn lowers real wage rate. To maintain the level of labor income, households must supply more labor, which reduces welfare. As a result, it is optimal for the planner to restrict labor hiring, because private agents do not internalize the effect of their actions on the aggregate prices and overestimate 
the marginal benefit of working. On the other hand, if more labor hours increase the price of domestic output, i.e. $\frac{\partial p_{t}^{H}}{\partial t_{t}}>0$, then it is socially optimal to subsidize labor hiring. The externality of individual production decision on aggregate relative prices is sometimes referred as "terms-of-trade externality" in the literature. In general, the direction of price movements to labor choice depends on the specifications of utility, technology and foreign demand functions. The parameter values of import and export share and the elasticity of substitution between home and foreign goods also impact this relationship.

Analogous to labor choice, capital accumulation is generally different under the two equilibria. The last term in (3.27) reflects the price effect that private agents do not take into account when making their investment decisions. Therefore, a planner discourages capital investment when additional output deteriorates the purchasing power of home intermediate goods, and encourage investment otherwise.

We have shown a terms-of-trade externality exists in this model and the competitive equilibrium is generally not optimal. Now let us see how the adoption of a semiopen capital account regime can move the allocations from competitive equilibrium toward optimal allocation. The country's aggregate resource constraint under semiopen capital account regime is written as,

$$
C_{t}+I_{t}-b_{t}^{F R} e_{t}=Q_{t}^{H} p_{t}^{H}-R_{t-1}^{*} b_{t-1}^{F R} e_{t} .
$$

By choosing the amount of foreign reserves a country accumulates, the government is able to control the resources that are available to the domestic households, thereby affecting their consumption, working and investment decisions.

Next we investigate the conditions under which a semi-open capital account cannot improve welfare in this model compared to open capital account. The results are summarized in proposition 1.

Proposition 1. A semi-open capital account regime cannot improve welfare compared to open capital account regime if one of the following conditions is met:

i). Home and foreign intermediate goods are perfect substitutes when produce final goods, i.e. $\mu \rightarrow \infty$.

ii). Demand for home exports are perfectly elastic, i.e. $\mu^{*} \rightarrow \infty$.

iii). The production of final goods does not use home intermediate goods, i.e. $v=1$ and $v^{*}=0$.

Proof. See Appendix B 
Intuitively, the ability for a planner to correct the terms-of-trade externality in this model hinges on her influence on relative prices of home output. This requires that first the home has some monopoly power over its output, and second, that the planner is able to change private behavior. In the three cases described in proposition 1 , the home loses its monopoly power over the goods it produces and relative prices of home goods are fixed at their steady state level. Hence, a planner cannot improve upon competitive equilibrium. Apart from those three conditions, in a semi-open capital account regime where foreign exchange interventions can affect private savings, a planner generally improves welfare by choosing a different allocation compared to the competitive one.

\section{CAlibration}

The model is calibrated to a quarterly frequency. The statistics for the data are computed from China data for the period 2000:Q1 to 2013:Q4. The parameter values are summarized in table 1 . The real interest rate is set to 4 percent annually, which gives us a discount factor $\beta$ of 0.99 . The risk aversion level $\sigma$ is assumed to be 2 . We set the inverse of the Frisch labor supply elasticity $\eta$ to be 2 as well. In China, the average imports and exports to GDP ratios are approximately $24 \%$ and $26 \%$ respectively, which implies the preference parameters for domestic goods in home and foreign country are $v=0.24$ and $v^{*}=0.26$. The value for elasticity of substitution between home and foreign intermediate goods $(\mu)$ typically ranges from 1 to 2 in the literature. We follow Chang, Liu and Spiegel (2015) to choose $\mu=\mu^{*}=1.5$, and they lie within the range estimated by Feenstra et al. (2014). We set the transaction cost parameter $\gamma_{f}=1 e-5$, to ensure that the model dynamics is not affected by this transaction cost.

For the intermediate goods firms, the production share of capital is set to 0.6 and the depreciation rate of capital is 0.05 , which implies a $20 \%$ annual depreciation rate. These numbers are higher than standard values calibrated to the U.S. economy in the literature, however they are necessary to replicate the high investment to GDP ratio and capital investment returns observed in China. I follow Gali and Monacelli (2005) by setting $\epsilon=6$, yielding a steady state mark-up of 1.2. The fraction of firms that cannot re-set their prices is assumed to be 0.66 , which implies that, on average, the prices will be reset every three quarters. Lastly, we specify the technology shock persistence to be 0.9 with standard deviation $1 \%$. We also experiment with 10 basis points foreign interest rate shocks with a persistence of 0.9 .

The data and model implied steady state values are reported in table 2. The investment to GDP is $43 \%$, which is consistent with the Chinese data. The government 
Table 1: Parameters: Quarterly

\begin{tabular}{lcc}
\hline \hline Statistic & Parameter & Value \\
\hline Households & & \\
Discount Factor & $\beta$ & 0.99 \\
Risk Aversion & $\sigma$ & 2 \\
Inverse of Frish Elasticity & $\eta$ & 2 \\
Labor Hours & $\chi$ & 8.65 \\
Preference for Foreign Goods & $v$ & 0.24 \\
Preference for Domestic Goods & $v^{*}$ & 0.26 \\
Elasticity of Subst. between Home and Foreign Goods & $\mu$ & 1.5 \\
Elasticity of Home Exports & $\mu^{*}$ & 1.5 \\
International Capital Adj. Cost & $\gamma_{f}$ & $1 \mathrm{e}-5$ \\
& & \\
Firms & & \\
Capital Share & $\alpha$ & 0.6 \\
Depreciation Rate & $\delta$ & 0.05 \\
Elasticity of Subst. between intermediate goods & $\epsilon$ & 6 \\
Calvo Pricing & $\omega$ & 0.66 \\
& & \\
Shocks & \multicolumn{2}{c}{} \\
Tech. Shock Persistence & $\rho_{a}$ & 0.9 \\
Tech. Shock Std. Dev. & $\sigma_{a}$ & 0.01 \\
Foreign Interest Rate Shock Persistence & $\rho_{R}^{*}$ & 0.9 \\
Foreign Interest Rate Std. Dev. & $\sigma_{R}^{*}$ & 0.001 \\
\hline
\end{tabular}

expenditure to GDP ratio is fixed at $14 \%$ based on the data. The domestic and foreign goods preference parameters $v$ and $v^{*}$ are chosen to match the steady state values for exports and imports to GDP ratio at $26 \%$ and $24 \%$ respectively. The consumption to GDP ratio is calculated as $40 \%$ based on the parameter values assumed in table 1 . Finally, although I do not target the net foreign asset position, the model implied steady state net foreign assets over GDP ratio is quite close to the one observed from the data at $49 \%$ and $42 \%$ respectively. Note here the open and semi-open capital account policy regimes imply an identical non-stochastic steady state.

The Ramsey planner's first order conditions are computed using the algorithm developed by Levin et al. (2006). The model is then solved by second-order perturbation methods. 
Table 2: Deterministic Steady States

\begin{tabular}{lcc}
\hline \hline Variable & Data & Models \\
\hline Consumption/GDP & 0.39 & 0.41 \\
Investment/GDP & 0.44 & 0.43 \\
Govt Spending/GDP & 0.14 & 0.14 \\
Exports/GDP & 0.27 & 0.26 \\
Imports/GDP & 0.24 & 0.24 \\
Net Foreign Assets/GDP & 0.42 & 0.49 \\
\hline
\end{tabular}

Data Source: China NBS, World Bank.

\section{Results: Flexible Prices}

This section analyzes the semi-open capital account regime under flexible prices. ${ }^{8}$ Without nominal rigidities, monetary policy does not affect the real allocations of resources and welfare. In this case, policy makers essentially have only one instrument, foreign exchange interventions, in addition to a closed capital account. This allows me to separate the welfare effect of foreign exchange interventions from monetary policy. In section 6, policy makers are given two instruments, monetary policy and foreign exchange interventions, which allows us to examine policy interactions.

\subsection{IMPULSE RESPONSES OF SHOCKS}

5.1.1 A DOMESTIC PRODUCTIVITY INCREASE Figure 4 reports the impulse response functions of selected macroeconomic variables to a one-percent positive domestic productivity shock. I assume the economy starts from its steady state. The figure plots percentage deviations of each variable from its steady state following the shock, over a 10-year period. The red dash-dot lines show the model dynamics under open capital account regime and the blue solid lines represent the impulse responses under semiopen capital account regime.

First, consider the competitive equilibrium. When the country becomes more productive, investment surges to take advantage of higher returns. Part of the increase in investment is funded by borrowing from the international bond market. The home wealth effect generates a higher demand for foreign goods, moreover the demand for investment also increases home imports. At the same time, the rise of domestic intermediate goods production leads to an expenditure-switching from foreign to domestic goods. The combined impact is the substitution effect dominates at first, causing net exports to drop to deficit. As the productivity falls back, the wealth effect becomes

\footnotetext{
${ }^{8}$ I set the Calvo parameter $\omega=1 e-6$ to model flexible prices.
} 
dominant and net exports swing back to surplus. The changes in terms of trade reflect this trade pattern. Throughout the period, more domestic output tends to push down the terms of trade, while the higher demand for foreign goods at the beginning deteriorates the terms of trade further. As a result, the real exchange rate depreciates.

To better understand the welfare gains from interventions, I proceed by adding capital controls and foreign exchange interventions in turn. In the closed capital account regime, consumption rises sharply after the productivity advance, but investment does not increase as much as free bond trade. On the one hand, international bond trade permits capital to flow to the most efficient use and improves productive efficiency. On the other hand, it affects the automatic consumption risk insurance provided by terms of trade, as stressed in Cole and Obstfeld (1991). As a consequence, the lifetime consumption level is lower. Heathcote and Perri (2014) finds that under certain parameter values, the terms of trade insurance against country specific shocks dominates, implying that living in financial autarky is welfare improving. Although not reported, the baseline calibration presented in this paper does not provide sufficient insurance for financial autarky alone to be welfare dominant. ${ }^{9}$

Nevertheless, when the government adopts the semi-open capital account regime, welfare is higher than with free bond trade. This is because the benevolent government is able to strike a balance between productive efficiency and consumption risk insurance with intervention as an additional policy tool. As we can see from figure 4, the government holds a different international bond position on behalf of the country in general compared to the one in open capital account regime. This is due to the fact that when an individual household makes his investment decision, he takes the prices of output sold in the international market as given. However, collective individual production decisions increase the total supply of domestic goods in the market and lower their prices, i.e. deteriorate the terms of trade. On the other hand, a Ramsey planner internalizes the effect of more domestic supply on terms of trade. Deviation from competitive equilibrium is desirable if the benefit of a favorable terms of trade under lower domestic supply outweighs the cost from losing some degree of intertemporal consumption smoothing. Notice that the direction of capital flow may not even be the same in these two regimes.

Also shown in figure 4, the Ramsey planner chooses to invest and work less, resulting in lower output and current account deficits. Overall, the terms of trade is more favorable with interventions than without. I demonstrate this point by calculating the

\footnotetext{
${ }^{9}$ I confirm the findings by Heathcote and Perri (2014)(not reported). Financial autarky can be welfare improving when the elasticity of substitution is low or when the import share is high.
} 
net present value of the difference in the terms of trade under the two scenarios. This measure, given below, is positive which means the overall terms of trade is more favorable with interventions.

$$
N P V(T o T)=(1-\beta) \sum_{t=0}^{\infty} \beta^{t}\left(T o T_{t}^{\mathrm{w} /}-T_{0} T_{t}^{\mathrm{w} / \mathrm{o}}\right)>0
$$

In practice, this optimal policy can be implemented in the following way: First of all, the government does not allow capital flows through the private sector. Initially when the private agents want to borrow from abroad, the public sector acts as a financial intermediary that borrows from the international bond market and lends to the domestic agents in local currency bonds, but at a smaller amount than the private sector's desired level. Later on, when the private sector wants to save, the government issues domestic bonds to force private sector to save at a higher rate than individual optimality and uses the proceeds to hold foreign bonds.

5.1.2 A FOREIGN INTEREST RATE RISE In this section, I consider the macroeconomic effects of a foreign interest rate hike. This experiment can be thought of as when the Fed raises U.S. interest rates, how should China intervene in the foreign exchange market to optimally respond to such an external shock. I report the impulse responses in figure 5. In open capital account regime, as illustrated by the dash-dot lines, a higher foreign interest rate induces home households to hold more foreign bonds. This drives down domestic investment and output. Home consumption falls as well, but labor hours rise. Home currency depreciates in real value and the terms of trade worsen initially. The domestic households switch to import less foreign goods and export more home goods because of the changes of terms of trade.

What should the government do to optimally cope with this external shock in a semi-optimal capital account regime? The blue solid lines in figure 5 shows that a benevolent government chooses to save less (or borrow more) in the international bond market compared to the free market allocation. This mitigates the fall of investment and output due to capital outflows. The terms of trade and real exchange rate change less drastically, such that the terms of trade is more favorable when the output is low and is less favorable otherwise. This manipulation of relative prices mitigates the fall of income due to lower output, stabilizes the economy, and improves welfare. To implement the optimal policy responses in practice, the Chinese government should borrow more than the private sector's desire from overseas and channel those external resources into domestic economy by paying back outstanding government bonds. This 
offsets some of the initial capital flight, and prevents RMB from sharp depreciation.

5.2 Welfare AND MAcroeconomic Volatility To evaluate welfare, I write household utility recursively as,

$$
\text { Welf } f_{t}=U\left(c_{t}, n_{t}\right)+\beta \mathbb{E}_{t} \text { Wel } f_{t+1} .
$$

The welfare gain is measured as a percentage of consumption that a household is willing to give up in order to live in an alternative economy rather than a benchmark economy. Specifically, the welfare gain $\tau$ is defined as,

$$
\mathbb{E}_{t} \sum_{t=0}^{\infty} \beta^{t} u\left[(1-\tau) c^{\text {alt }}, l^{\text {alt }}\right]=\mathbb{E}_{t} \sum_{t=0}^{\infty} \beta^{t} u\left(c^{\text {ben }}, l^{\text {ben }}\right) .
$$

Notice here we follow Schmitt-Grohé and Uribe (2006) to condition the initial state being the deterministic steady state and then compute the expected welfare in different policy regimes. Given that the non-stochastic steady state is the same across regimes in this model, this choice of initial state guarantees an identical starting point under all polices and takes into consideration the transition dynamics leading to the stochastic steady state.

5.2.1 Productivity SHOcKS Table 3 presents the macroeconomic volatility of selected variables under alternative policy regimes relative to the benchmark, subject to a one percent home TFP shock. Recall that in the benchmark model, the home country's bond positions are determined competitively by the households without government interventions and prices are flexible. The second column shows the stability of the flexible price equilibrium in a semi-open capital account regime when foreign exchange interventions are conducted in a Ramsey manner. In contrast to the free flow equilibrium, most of the macroeconomic variables exhibit less fluctuations except aggregate inflation and nominal exchange rate appreciation rate. Stabilizing the economy brings a welfare gain of $0.006 \%$ consumption equivalence.

In a semi-open capital account regime, the government is permitted to accumulate foreign bonds through sterilized interventions. This improves productive efficiency by allowing capital to flow to the highest returns. At the same time, the planner internalizes the terms-of-trade externality when choosing the bond position to ensure the country does not over produce and determine the terms of trade. These two considerations offset each other and lead to less volatile capital flows. This is consistent with the finding of Farhi and Werning (2014) in which the authors suggest the use of "leaning 
against the wind" capital controls to smooth out capital flows. Here, I show optimal interventions in semi-open capital account regime stabilizes capital flows without the use of state-dependent capital controls.

5.2.2 Foreign INTEREST RATE SHOCKS The macroeconomic stability looks similar when foreign interest rate shocks hit the home economy. Table 4 displays the resulting volatilities. The welfare gain from adopting a semi-open capital account regime is sizable compared to the benchmark, about $0.626 \%$ consumption equivalence each period. Almost all macroeconomic variables are more stable than in open capital account regime. The Ramsey planner picks the optimal path of international borrowing and saving to influence domestic production so that the purchasing power of home production is high when consumption is low. This stabilizes the economy and improves welfare.

Overall, the real exchange rate exhibits less volatility when foreign exchange interventions are conducted optimally under capital controls. This can be understood as a correction of the terms-of-trade externality and provides a rationale for real exchange rate targeting. Nevertheless, the nominal exchange rate appreciation rate actually fluctuates more drastically when the economy is subject to domestic productivity shocks. This makes identifying the source of disturbance a priority to policy makers if they consider nominal exchange rate targeting.

\section{Results: STICKy PRICES}

The analysis so far has concentrated on the real side of the economy. When prices are flexible, monetary policy is neutral and does not affect real allocations, nor welfare. In this section, I extend the model to include sticky prices. This not only generates another source of inefficiency, it also gives policy makers an additional effective policy tool, the monetary policy interest rate. I examine how the monetary policy and foreign exchange interventions interact to deal with the inefficiencies presented in the extended model.

The results show that these two policy instruments have separate roles. While monetary policy effectively reduces domestic price distortions, foreign exchange interventions under capital controls are particularly useful to correct the terms-of-trade externality. In fact, the optimal monetary policy returns the economy to nearly flexible price allocations, while the interventions help to capture all the welfare gains from internalizing the terms-of-trade externality. This can be seen from comparing the left and right panel of tables 3 and 4 . The left and right panels are almost identical, which indicates 
the macroeconomic stabilities and welfare are very close with or without price distortions and monetary policy subject to either domestic TFP shocks or foreign interest rate shocks.

To make sense of this result, let us break down the table by comparing column by column. First, the first and third column are equilibria in an open capital account regime. These two columns indicate that optimal monetary policy nearly undoes all the price distortions and restores the flexible price equilibrium, even if an incentive to deviate from it in a beneficial way to influence terms of trade, as noted by Corsetti and Pesenti (2001) among others, exists. The second and last columns show equilibria in semi-open capital account regime under flexible prices and sticky prices respectively. While not exact, they look very similar to each other. ${ }^{10}$ I conclude that in this model with baseline calibration, policy makers should use monetary policy to target domestic price frictions, while adopting a semi-open capital account regime to target-terms oftrade externalities.

Since the general shapes of impulse response functions look very similar to those under flexible prices, I focus on the explanations of nominal variables. After a positive productivity shock, higher aggregate supply drives down the domestic price level, but also depreciates home currency, making foreign goods more expensive. Higher import prices pull up home aggregate inflation and the nominal exchange rate depreciates. The optimal monetary policy interest rate rises in response to stabilize the economy. Notice that the changes of domestic inflation are quantitatively very small, indicating the flexible price equilibrium is replicated. If a foreign interest rate increase occurs, aggregate demand falls and domestic inflation drops. However, the exchange rate still depreciates due to the capital flights, and as a result, aggregate inflation rises. Monetary policy lowering the interest rate to combat the negative spillover effects of foreign interest rate hike.

\section{SENSITIVITy ANALYSIS}

In this section, I perform sensitivity analysis to check the impact of parameter values on my results. I altered four key parameters, the elasticity of substitution between home and foreign goods in producing final goods, the elasticity of foreign demand for home exports, and home export and import shares. Table 5 and 6 present the welfare gains under different parameter values across policy regimes.

The first two variations of parameter values make home goods less substitutable,

\footnotetext{
${ }^{10}$ Most of them differ by a magnitude of $1 \mathrm{e}-4$.
} 
and the last variation indicates greater trade integration. Overall, the results confirm the findings of proposition 1. By comparing welfare gains across different parameterizations, I find when the constrained planner's ability to manipulate relative prices of home produced goods increases, it amplifies the welfare gains from foreign exchange interventions. Also notice that real exchange rate becomes less volatile in the semiopen capital account regime across different parameterizations.

The last two columns show the welfare gains when the price adjustments are sluggish and monetary policy is conducted optimally. Although quantitatively small, the optimal monetary policy under sticky prices in an open capital account regime achieves a welfare gain compared to flexible prices allocations. This is not surprising, as the planner's greater ability to manage relative prices gives monetary policy a stronger incentive to deviate from the flexible price equilibrium, and results a better outcome. The last column is almost identical to the first column, indicating the joint use of monetary policy and foreign exchange interventions is sufficient to bring the equilibrium back to the allocations under flexible price with semi-open capital account. Those results hold under both TFP and foreign interest rate shocks. Overall, the main result that monetary policy alone restores the economy back to flexible price equilibrium and interventions correct most of the terms-of-trade externality still holds.

\section{CONCLUSION}

This paper studies optimal foreign exchange interventions in a semi-open capital account policy regime in which the public sector has access to the international bond market but the private sector does not. This policy regime corresponds to the Chinese economy. I find that optimal interventions under capital controls can improve welfare over a fully open capital account by strategically manipulating the terms of trade. In particular, when an economy receives positive productivity shocks, the Ramsey planner accumulates foreign reserves and forces the private sector to save more than their desired level. When the foreign country raises world interest rate, it is optimal for the home economy to restrict private capital flight. In these two cases, the home economy resists real exchange rate movements.

In the presence of domestic nominal rigidity, interventions can lead to a welfare gain even if monetary policy is set optimally. I find separate roles for these two policy instruments. While monetary policy more effectively eliminates domestic price distortions, foreign exchange interventions more efficiently correct terms-of-trade external-

ities. Notice that the model assumes perfect pass-through of exchange rate which is 
not supported by empirical evidence. An incomplete pass-through that brings another price distortion may break down the dichotomy of monetary policy and interventions. I leave this for future research. 
Figure 4: A Positive One-Percent TFP Shock: Flexible Prices
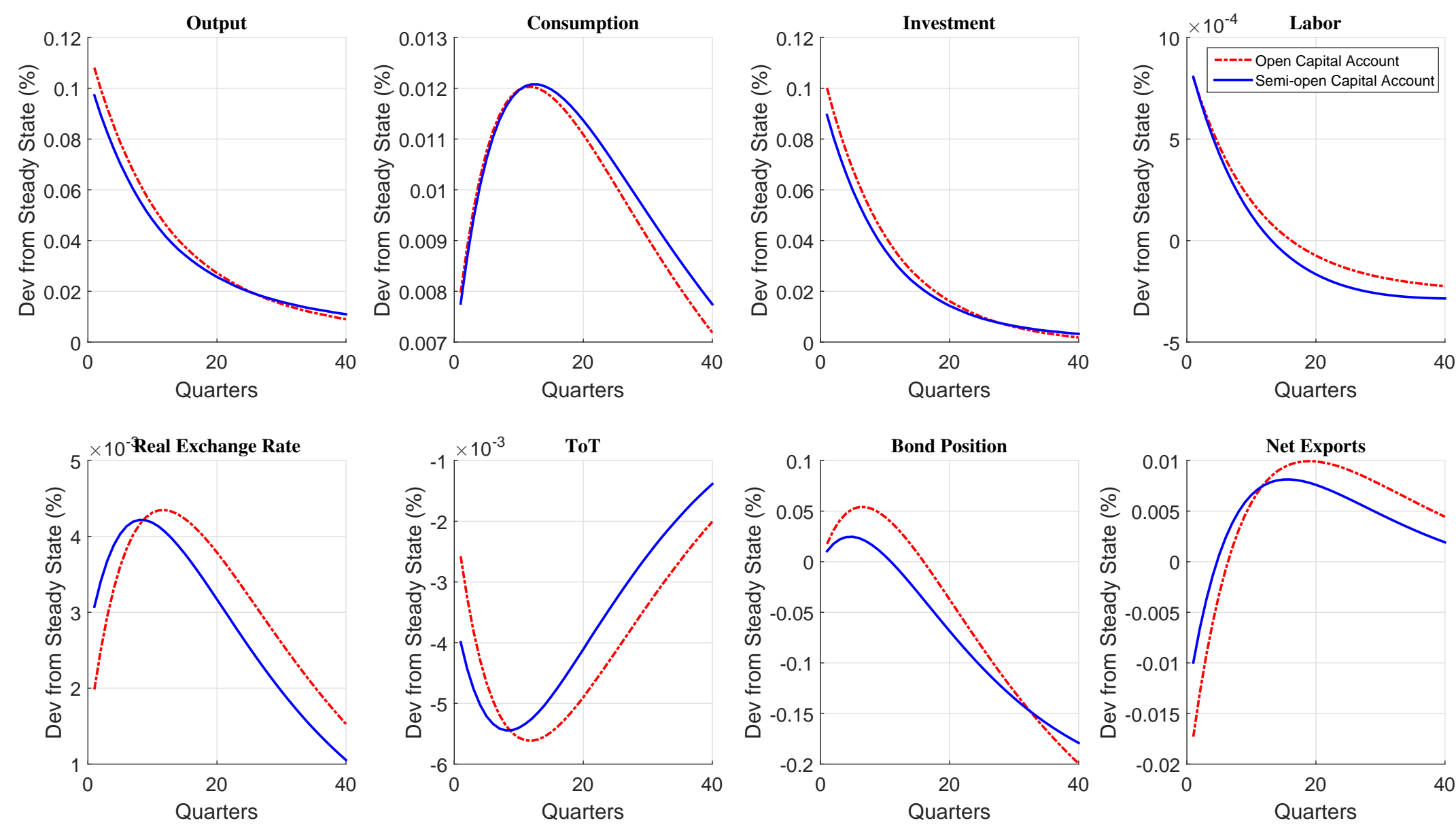

Note: Impulse response functions to a positive 1\% domestic productivity shock under flexible prices. Red dash-dot line: open capital account. Blue solid line: optimal foreign exchange interventions in semi-open capital account. 
Figure 5: A Positive 10 Basis Points Foreign Interest Rate Shock: Flexible Prices


Note: Impulse response functions to a negative $0.1 \%$ foreign interest rate shock under flexible prices. Red dash-dot line: open capital account. Blue solid line: optimal foreign exchange interventions in semi-open capital account. 
Figure 6: A Positive One-Percent TFP Shock: Sticky Prices
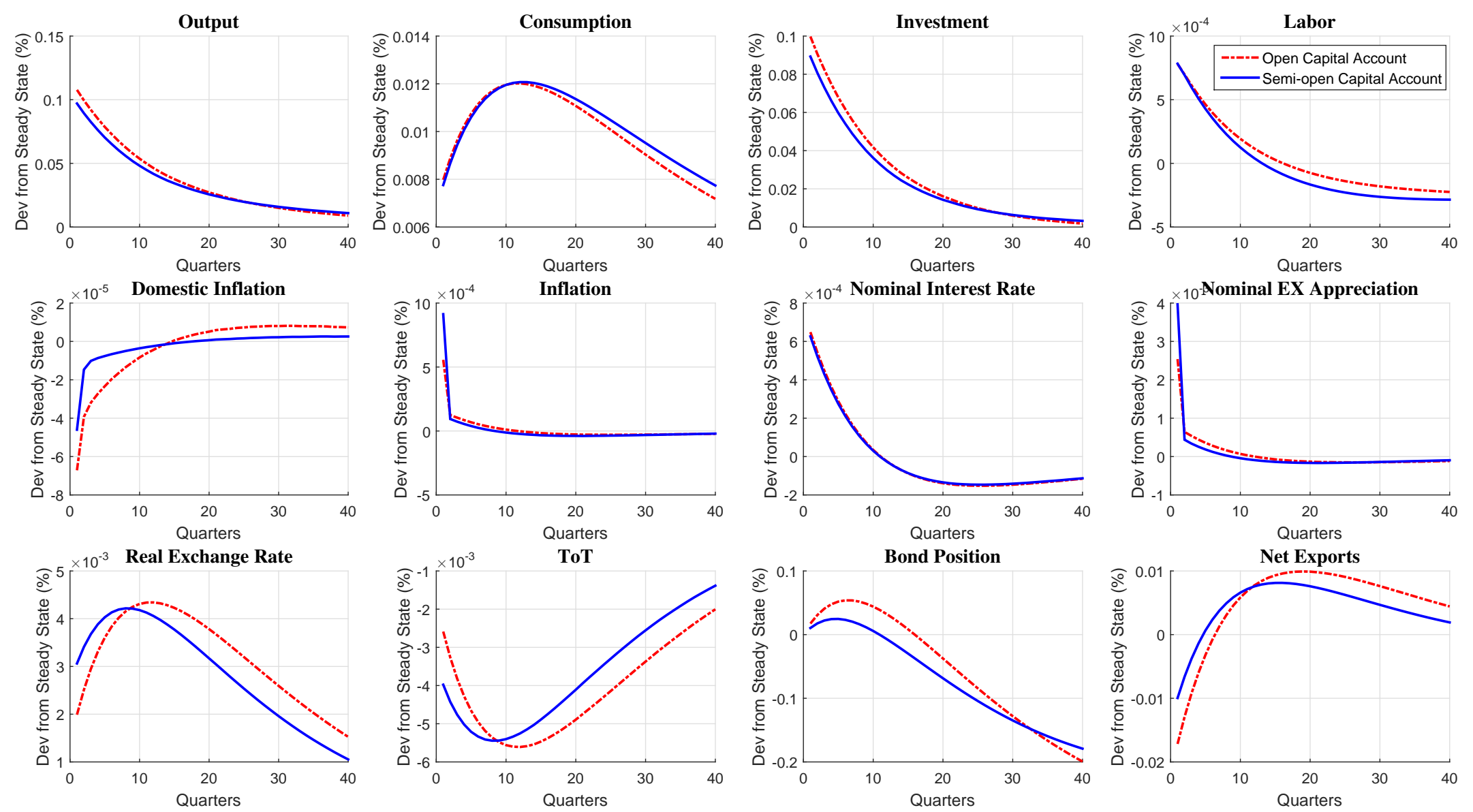

Note: Impulse response functions to a positive $1 \%$ domestic productivity shock under sticky prices. Red dash-dot line: open capital account. Blue solid line: optimal foreign exchange interventions in semi-open capital account. 
Figure 7: A Positive 10 Basis Points Foreign Interest Rate Shock: Sticky Prices
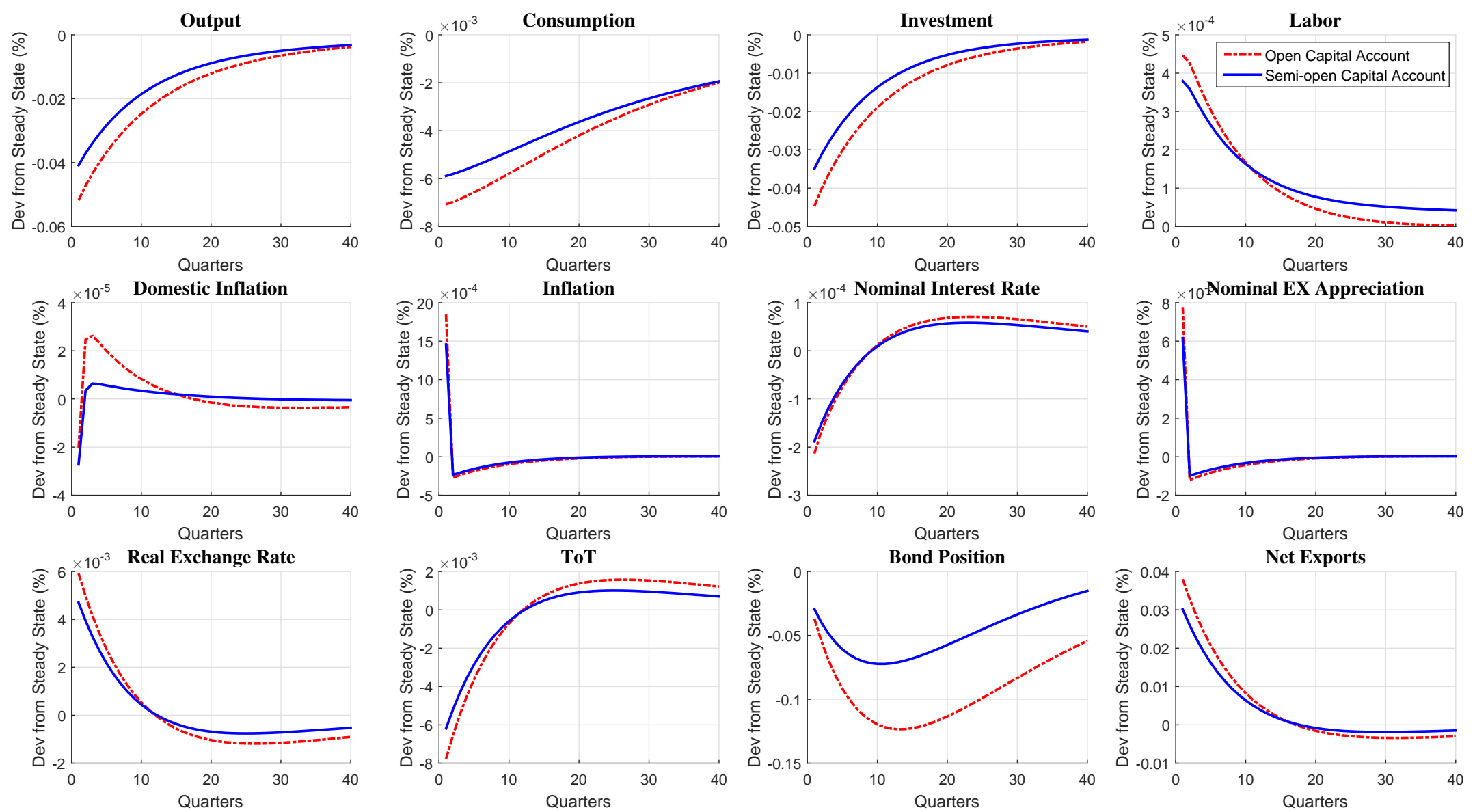

Note: Impulse response functions to a negative $0.1 \%$ foreign interest rate shock under sticky prices. Red dash-dot line: open capital account. Blue solid line: optimal foreign exchange interventions in semi-open capital account. 
Table 3: Macroeconomic Volatility and Welfare under Alternative Policy Regimes (subject to TFP shocks)

\begin{tabular}{lcccc}
\hline \hline & \multicolumn{2}{c}{ Flexible Prices } & \multicolumn{2}{c}{ Sticky Prices } \\
\hline Variable & $\begin{array}{c}\text { Open CA } \\
\text { (benchmark) }\end{array}$ & Semi-open CA & Open CA & Semi-open CA \\
\hline Mean (relative to the benchmark) & & & & \\
Consumption & 1 & 1 & 1 & 1 \\
Labor & 1 & 1 & 1 & 0.91 \\
\hline Standard Deviation (relative to the benchmark) & & 1 & 0.99 \\
Output & 1 & 0.91 & 1 & 0.88 \\
Consumption & 1 & 0.99 & 1 & 0.95 \\
Investment & 1 & 0.88 & 1 & 0.41 \\
Labor & 1 & 0.95 & 0.99 & 1.50 \\
Domestic Inflation & 1 & 0.42 & 1 & 0.97 \\
Aggregate Inflation & 1 & 1.50 & 1 & 1.42 \\
Nominal Interest Rate & 1 & 0.97 & 1 & 0.86 \\
Nominal EX Appreciation Rate & 1 & 1.42 & 1 & 0.94 \\
Net Exports & 1 & 0.86 & 1 & 0.91 \\
International Bond Holdings & 1 & 0.94 & 1 & 0.91 \\
Real Exchange Rate & 1 & 0.91 & $0 \%$ & $0.006 \%$ \\
Terms of Trade & 1 & 0.91 & $0.006 \%$ & 1 \\
\hline \hline Welfare Gain & $0 \%$ &
\end{tabular}

Note: Open CA: open capital account. Semi-open CA: semi-open capital account.

The standard deviation of each variable in different policy regimes is measured as relative to the benchmark standard deviation. All welfare gains are relative to the benchmark. 
Table 4: Macroeconomic Volatility and Welfare under Alternative Policy Regimes (subject to foreign interest rate shocks)

\begin{tabular}{lcccc}
\hline \hline & \multicolumn{2}{c}{ Flexible Prices } & \multicolumn{2}{c}{ Sticky Prices } \\
\hline Variable & $\begin{array}{c}\text { Open CA } \\
\text { (benchmark) }\end{array}$ & Semi-open CA & Open CA & Semi-open CA \\
\hline Mean (relative to the benchmark) & & & & \\
Consumption & 1 & 1.01 & 1 & 1.01 \\
Labor & 1 & 0.99 & 1 & 0.99 \\
\hline Standard Deviation (relative to the benchmark) & & & \\
Output & 1 & 0.79 & 1 & 0.79 \\
Consumption & 1 & 0.96 & 1 & 0.96 \\
Investment & 1 & 0.77 & 1 & 0.77 \\
Labor & 1 & 1.10 & 1 & 1.09 \\
Domestic Inflation & 1 & 0.74 & 0.87 & 0.65 \\
Aggregate Inflation & 1 & 0.81 & 1 & 0.81 \\
Nominal Interest Rate & 1 & 0.87 & 1.01 & 0.88 \\
Nominal EX Appreciation Rate & 1 & 0.81 & 1 & 0.81 \\
Net Exports & 1 & 0.83 & 1 & 0.83 \\
International Bond Holdings & 1 & 1.18 & 1 & 1.18 \\
Real Exchange Rate & 1 & 0.84 & 1 & 0.84 \\
Terms of Trade & 1 & 0.84 & 1 & 0.84 \\
\hline \hline Welfare Gain & $0 \%$ & $0.626 \%$ & $0 \%$ & $0.626 \%$ \\
\hline Note: Open CA: open capital account. Sem
\end{tabular}

Note: Open CA: open capital account. Semi-open CA: semi-open capital account.

The standard deviation of each variable in different policy regimes is measured as relative to the benchmark standard deviation. All welfare gains are relative to the benchmark. 
Table 5: Exchange Rates and Welfare Gains under Different Parameterizations:

(subject to TFP shocks)

\begin{tabular}{cccccc}
\hline \hline & \multirow{2}{*}{ Variables } & \multicolumn{2}{c}{ Flexible Prices } & \multicolumn{2}{c}{ Sticky Prices } \\
& & Open CA & Semi-open CA & Open CA & Semi-open CA \\
\hline \multirow{2}{*}{ Baseline } & Real EX & 1 & 0.93 & 1 & 0.93 \\
& Welfare & $0 \%$ & $0.006 \%$ & $0 \%$ & $0.006 \%$ \\
\hline \multirow{2}{*}{ Lower Elasticity of Subst. $(\mu=1)$} & Real EX & 1 & 0.94 & 1 & 0.94 \\
& Welfare & $0 \%$ & $0.011 \%$ & $0 \%$ & $0.011 \%$ \\
\hline \multirow{2}{*}{ Less Elastic Home Exports $\left(\mu^{*}=1\right)$} & Real EX & 1 & 0.94 & 1 & 0.94 \\
& Welfare & $0 \%$ & $0.009 \%$ & $0 \%$ & $0.009 \%$ \\
\hline \multirow{2}{*}{ Greater Trade Integration $\left(v=0.38, v^{*}=0.4\right)$} & Real EX & 1 & 0.86 & 1 & 0.86 \\
& Welfare & $0 \%$ & $0.011 \%$ & $0 \%$ & $0.011 \%$ \\
\hline
\end{tabular}

Note: Open CA (benchmark): open capital account. Semi-open CA: semi-open capital account. Real EX: real exchange rate. The standard deviation of real exchange rate in different policy regimes is measured as relative to the benchmark standard deviation. All welfare gains are relative to the benchmark. 
Table 6: Exchange Rates and Welfare Gains under Different Parameterizations:

(subject to foreign interest rate shocks)

\begin{tabular}{|c|c|c|c|c|c|}
\hline & \multirow{2}{*}{ Variables } & \multicolumn{2}{|c|}{ Flexible Prices } & \multicolumn{2}{|c|}{ Sticky Prices } \\
\hline & & Open CA & Semi-open CA & Open CA & Semi-open CA \\
\hline \multirow{2}{*}{ Baseline } & Real EX & 1 & 0.86 & 1 & 0.86 \\
\hline & Welfare & $0 \%$ & $0.626 \%$ & $0 \%$ & $0.626 \%$ \\
\hline \multirow{2}{*}{ Lower Elasticity of Subst. $(\mu=1)$} & Real EX & 1 & 0.88 & 1 & 0.88 \\
\hline & Welfare & $0 \%$ & $0.937 \%$ & $0 \%$ & $0.937 \%$ \\
\hline \multirow{2}{*}{ Less Elastic Home Exports $\left(\mu^{*}=1\right)$} & Real EX & 1 & 0.88 & 1 & 0.88 \\
\hline & Welfare & $0 \%$ & $1.235 \%$ & $0.001 \%$ & $1.235 \%$ \\
\hline \multirow{2}{*}{ Greater Trade Integration $\left(v=0.38, v^{*}=0.4\right)$} & Real EX & 1 & 0.7 & 1 & 0.7 \\
\hline & Welfare & $0 \%$ & $0.612 \%$ & $0.001 \%$ & $0.612 \%$ \\
\hline
\end{tabular}

Note: Open CA (benchmark): open capital account. Semi-open CA: semi-open capital account. Real EX: real exchange rate. The standard deviation of real exchange rate in different policy regimes is measured as relative to the benchmark standard deviation. All welfare gains are relative to the benchmark. 


\section{REFERENCES}

BaCchetta, P., K. Benhima, And Y. KALAntZis (2013): “Capital Controls with International Reserve Accumulation: Can This Be Optimal?," American Economic Journal: Macroeconomics, 5(3), 229-62.

Benigno, G., And P. Benigno (2003): "Price stability in open economies," The Review of Economic Studies, 70(4), 743-764.

BetTS, C., AND M. B. Devereux (1996): “The exchange rate in a model of pricing-tomarket," European Economic Review, 40(3), 1007-1021.

BIANCHI, J. (2011): "Overborrowing and Systemic Externalities in the Business Cycle," The American Economic Review, 101(7), 3400.

Chamon, M., J. D. Ostry, And A. Ghosh (2012): “Two Targets, Two Instruments: Monetary and Exchange Rate Policies in Emerging Market Economies," Discussion paper, International Monetary Fund.

ChANG, C., Z. LIU, AND M. M. SPIEgel (2015): “Capital controls and optimal Chinese monetary policy," Journal of Monetary Economics, 74, 1-15.

ChINN, M. D., AND H. ITO (2006): “What matters for financial development? Capital controls, institutions, and interactions," Journal of Development Economics, 81(1), 163192.

COLE, H. L., AND M. OBSTFELD (1991): “Commodity trade and international risk sharing: How much do financial markets matter?," Journal of Monetary Economics, 28(1), $3-24$.

Corsetti, G., And P. Pesenti (2001): “Welfare and Macroeconomic Interdependence," Quarterly Journal of Economics, pp. 421-445.

DE PAOLI, B. (2009): "Monetary policy and welfare in a small open economy," Journal of International Economics, 77(1), 11-22.

DE PAOLI, B., AND A. LiPINSKA (2013): "Capital Controls: a normative analysis," FRB of New York Staff Report, (600).

Devereux, M. B., AND J. Yetman (2014): “Globalisation, pass-through and the optimal policy response to exchange rates," Journal of International Money and Finance. 
EICHENGREEN, B., AND A. Rose (2014): “Capital controls in the 21st century," Journal of International Money and Finance, 48, 1-16.

FARHI, E., AND I. WERNING (2012): “Dealing with the trilemma: Optimal capital controls with fixed exchange rates," NBER Working Paper, (w18199).

- (2014): "Dilemma Not Trilemma? Capital Controls and Exchange Rates with Volatile Capital Flows," IMF Economic Review, 62(4), 569-605.

Feenstra, R. C., P. A. Luck, M. Obstfeld, And K. N. Russ (2014): “In search of the Armington elasticity," Discussion paper, National Bureau of Economic Research.

GALI, J., AND T. MONACELLI (2005): “Monetary policy and exchange rate volatility in a small open economy," The Review of Economic Studies, 72(3), 707-734.

Heathcote, J., And F. Perri (2014): “On the Desirability of Capital Controls,” Federal Reserve Bank of Minneapolis, working paper.

JeAnne, O., And A. KorineK (2010): “Excessive volatility in capital flows: A pigouvian taxation approach," Discussion paper, National Bureau of Economic Research.

KORINEK, A. (2010): “Regulating Capital Flows to Emerging Markets: An Externality View," .

Levin, A. T., A. OnAtski, J. Williams, and N. M. Williams (2006): “Monetary policy under uncertainty in micro-founded macroeconometric models," in NBER Macroeconomics Annual 2005, Volume 20, pp. 229-312. MIT Press.

PRASAD, N. (2014): “Sterilized interventions and capital controls," .

SChMitT-Grohé, S., AND M. URibe (2003): “Closing small open economy models," Journal of international Economics, 61(1), 163-185.

SChmitt-Grohé, S., And M. Uribe (2006): “Optimal simple and implementable monetary and fiscal rules: Expanded version," Discussion paper, National Bureau of Economic Research.

SChmitT-Grohé, S., AND M. URIBE (2012): “Prudential policy for peggers," Discussion paper, National Bureau of Economic Research.

SonG, Z., K. Storesletten, and F. Zilibotti (2011): “Growing like china," The American Economic Review, 101(1), 196-233. 


\section{A Competitive Equilibrium Optimality CONDITIONS}

First order condition with respect to consumption

$$
c_{t}^{-\sigma}=\lambda_{t}
$$

Euler equation

$$
\beta R_{t} E_{t} \frac{\lambda_{t+1}}{\pi_{t+1}}=\lambda_{t}
$$

First order condition with respect to internation bonds

$$
\lambda_{t}\left[1-\gamma_{f}\left(b_{T}^{F} e_{t}-b^{F} e\right)\right]=\beta E_{t} \lambda_{t+1} \frac{e_{t+1}}{e_{t}} \frac{R_{t}^{*}}{\pi_{t+1}^{*}}
$$

Labor supply

$$
\chi l_{t}^{\eta}=\lambda_{t} w_{t}
$$

Capital supply

$$
1=\beta E_{t} \frac{\lambda_{t+1}}{\lambda_{t}}\left[r_{t+1}^{k}+(1-\delta)\right]
$$

Labor demand

$$
w_{t}=(1-\alpha) \frac{p_{t}^{H} Q_{t}^{H}}{l_{t}}
$$

Capital demand

$$
r_{t}^{k}=\alpha \frac{p_{t}^{H} Q_{t}^{H}}{k_{t}}
$$

Home demand for domestic intermediate goods

$$
y_{t}^{H}=(1-v)\left(p_{t}^{H}\right)^{-\mu} y_{t}
$$

Home demand for foreign intermediate goods

$$
y_{t}^{F}=v\left(p_{t}^{F}\right)^{-\mu} y_{t}
$$


Foreign demand for domestic intermediate goods

$$
y_{t}^{H^{*}}=v^{*}\left(p_{t}^{H^{*}}\right)^{-\mu^{*}} y_{t}^{*}
$$

Firms' optimal price adjustments at home

$$
\begin{gathered}
F_{t}^{p}=c_{t}^{-\sigma} \pi_{t}^{*} y_{t}^{H}+\beta \psi E_{t}\left(\frac{\pi_{t}^{*}}{\pi_{t+1}^{*}}\right)\left(\frac{1}{\pi_{t+1}^{H}}\right)^{1-\epsilon} F_{t+1}^{p} \\
K_{t}^{p}=c^{-\sigma} m c_{t} y_{t}^{H}+\beta \psi E_{t}\left(\frac{1}{\pi_{t+1}^{H}}\right)^{-\epsilon} K_{t+1}^{P} \\
\epsilon K_{t}^{p}=(\epsilon-1) F_{t}^{p}
\end{gathered}
$$

Price dispersions

$$
\delta_{t}^{p}=(1-\psi)\left(\pi_{t}^{*}\right)^{-\epsilon}+\psi\left(\frac{1}{\pi_{t}^{H}}\right)^{-\epsilon} \delta_{t-1}^{p}
$$

Domestic intermediate goods price level

$$
1=\psi\left(\frac{1}{\pi_{t}^{H}}\right)^{1-\epsilon}+(1-\psi)\left(\pi_{t}^{*}\right)^{1-\epsilon}
$$

\section{B Proof of Proposition 1}

Rewrite the demand function for home intermediate goods (3.7) as the following,

$$
p_{t}^{H}=\left[(1-v)\left(\frac{y_{t}}{y_{t}^{H}}\right)\right]^{\frac{1}{\mu}} .
$$

i). When the home and foreign goods are perfect substitutes in producing final goods, $\mu \rightarrow \infty$, these two goods become identical and they should be sold at the same price. Therefore, there is no way the planner can alter their relative prices by changing the relative supply of home goods. We can see that also from the equation (B.1). When $\mu \rightarrow \infty, p_{t}^{H} \rightarrow 1$ no matter what values $\frac{y_{t}}{y_{t}^{H}}$ takes.

ii). Rewrite the demand function for home intermediate good exports (??) as the 
following,

$$
p_{t}^{H^{*}}=\left[\left(1-v^{*}\right)\left(\frac{y_{t}^{*}}{y_{t}^{H^{*}}}\right)\right]^{\frac{1}{\mu^{*}}}
$$

When the demand for home exports are perfectly elastic, $\mu^{*} \rightarrow \infty$, the prices of home exports $p_{t}^{H^{*}} \rightarrow 1$. This implies the home goods and foreign imports prices, $p_{t}^{H}$ and $p_{t}^{F}$, become perfectly correlated. We can see that by using the two law of one price relationships: $P_{t}^{H^{*}} S_{t}=P_{t}^{H}$ and $P^{F^{*}} S_{t}=P_{t}^{F}$ to get $\frac{p_{t}^{H}}{p_{t}^{F}}=1$ where we normalize the exogenous foreign price level $P_{t}^{F^{*}}=1$. This in turn implies the planner is not able to manipulate the relative prices by altering the allocation.

iii). When the final good productions do not involve home intermediate goods, $v=0$ and $v^{*}=0$, then $p_{t}^{H}=0$. This means home intermediate output worth nothing in the local and international markets and home should never produce any. What naturally follows is that the planner cannot influence the purchasing power of home output by changing the supplies. 